\title{
Dimethyl Carbonate as a Promising Oxygenated Fuel for Combustion: A Review
}

\author{
Ayoub O. G. Abdalla ${ }^{1,2}$ and Dong Liu ${ }^{1,2, *}$ \\ 1 MIIT Key Laboratory of Thermal Control of Electronic Equipment, School of Energy and Power Engineering, \\ Nanjing University of Science and Technology, Nanjing 210094, China; ayoub_gamar@njust.edu.cn \\ 2 Advanced Combustion Laboratory, School of Energy and Power Engineering, Nanjing University of Science \\ and Technology, Nanjing 210094, China \\ * Correspondence: dongliu@njust.edu.cn; Tel.: +86-25-8431-5475; Fax: +86-25-8431-4960
}

Received: 15 May 2018; Accepted: 6 June 2018; Published: 14 June 2018

check for updates

\begin{abstract}
Energy shortage and environmental problems are two dominant subjects. Dimethyl carbonate (DMC) is one of the oxygenated fuels with increasing interest as the alternative to diesel fuel or additive for conventional hydrocarbon fuels. In the last decade, comprehensive studies on DMC have been carried out in terms of synthesis, use, and oxidation and combustion mechanism. DMC synthesis from greenhouse gas such as carbon dioxide can achieve the carbon circulation between air and fuel. Ethylene carbonate route is one of the most promising ways to utilize carbon dioxide and synthesize DMC in terms of particle efficiency, energy consumption per one unit of product, and net carbon dioxide emission. In addition, the results show that pure DMC in compression ignition (CI) engines or DMC addition in diesel/gasoline could decrease emissions significantly. Moreover, DMC pyrolysis form carbon dioxide before carbon monoxide which is different from other oxygenated fuels. However, DMC can produce formaldehyde during oxidation process in high concentration, which is harmful to the environment and human health as well. The present DMC kinetic model needs to update the major reactions constant through recognizing the initial decomposition routes and low-temperature oxidation. In addition, further studies on the DMC/hydrocarbon fuels mixtures for the interaction chemistry are needed.
\end{abstract}

Keywords: DMC; oxygenated fuel; emissions; performance; oxidation; decomposition

\section{Introduction}

In this century, along with the depletion of fossil fuels, energy consumption is expected to reach 180, $000 \mathrm{GWh}$ /year by 2020 [1]. Conventional hydrocarbon fuels will become limited and very expensive in the near future. Continuous increase of oil consumption will raise the pollutants in the atmosphere. Consequently, strict pollutant emissions laws have been imposed by many government agencies around the world. To overcome these problems, new alternative fuels or additives were necessary for the conventional hydrocarbon fuels development [2,3]. As renewable non-conventional hydrocarbon fuels, oxygenated fuels either used directly as fuel or as additives have shown potential to reduce pollutants from internal combustion (IC) engines under equivalent conditions. In ideal oxygenated fuels, each oxygen atom is bonded to one carbon atom to form carbon monoxide. Therefore, the formation of $C-C$ bonds are inhibited which originally can lead to produce soot. Hydrocarbon fuel additives used in IC engines are separated into four categories: cetane and octane improvers (for diesel and gasoline engines, respectively), cleaning detergents for fuel injection system, combustion reaction enhancers, and oxygenates.

Dimethyl carbonate (DMC, $\left.\mathrm{CH}_{3} \mathrm{O}(\mathrm{C}=\mathrm{O}) \mathrm{OCH}_{3}\right)$, a carbonate ester, is a flammable liquid, has pleasant odor, is colorless, is transparent, and smells similar to methanol. In recent years, it has been 
recommended as an alternative fuel or oxygenated additive fuel for diesel/gasoline fuel by many researchers [4-8]. DMC has excellent features such as: (1) non-toxic production, environmentally friendly, non-corrosive, and safe handling [9]; (2) high oxygen content, $53.28 \%$ by weight, which plays an important role in suppressing the soot precursor concentration in fuel-rich combustion zone through $\mathrm{OH}$ radical [10]; (3) 100\% miscibility in fossil fuels (diesel and gasoline) [7,11]; (4) relatively high hydrogen to carbon (H/C) ratio [12]; (5) absence of carbon-carbon links in its molecular structure [13]; (6) low boiling point, which is important in spray atomization and mixing [13]; (7) decomposes to form methoxyformyl radical $\left(\mathrm{CH}_{3} \mathrm{OC}=\mathrm{O}\right)$, which is an intermediate key to reduce soot formation [14]; and (8) low carbon to oxygen $(\mathrm{C} / \mathrm{O})$ ratio [15].

Methyl tertiary butyl ether (MTBE, $\mathrm{C}_{5} \mathrm{H}_{12} \mathrm{O}$ ) has been used as an octane enhancer of gasoline fuel to reduce the exhaust emissions from gasoline engines $[16,17]$. Some governments prohibited or limited the percentage of MTBE in premium unlimited gasoline fuel because MTBE has an environmental effect on the ground-water and surface-water contamination and is categorized as a possible human health hazard compound by the United States Environmental Protection Agency (US EPA) [18-21]. Since the 1980s, DMC has been introduced as an oxygenated option for replacing MTBE in commercial gasoline [22-25]. In addition, DMC burns faster than MTBE when DMC is blended with gasoline under lean condition [7] and needs 4.5 times lower amount than MTBE to obtain the same level of oxygen in the mixture [26].

Some researchers have added dimethoxymethane (DMM, $\mathrm{C}_{3} \mathrm{H}_{8} \mathrm{O}_{2}$ ) before as oxygenated additive to conventional diesel fuel. Researchers found that, in terms of smoke emissions, the addition of ethers is more effective than alcohols [27] while alcohols structure is better than ester [28]. However, DMC demonstrated better results than several ethers to reduce the soot precursors formation such as acetylene, propylene, and ethylene [29].

The historical synthetic route to DMC is based on the methanolysis of toxic and corrosive phosgene. In fact, since the 1980s, it has no longer been produced from phosgene. Nowadays, several routes of DMC production have been industrialized. UBE and Enichem (Italy) have developed carbonylation of methanol with oxygen [9]. However, phosgene-free routes still suffer from toxic, corrosive, and explosive compounds. To overcome those problems and to balance the carbon between air and fuel by circulation, DMC synthetic from carbon dioxide as a chemical feedstock was introduced by many researchers. A considerable effort has been straightforward by using various catalysts. In this way, DMC production can be more economical and efficient.

From Table 1, conclusions can be reached that DMC has lower $C / O$ ratio $(0.75)$ compared to other oxygenated fuels $(1.5,3.75$, and 1.13 for ethanol, MTBE, and DMM, respectively), which has effects on the maximum concentrations of intermediate species and soot precursors in rich flames [15,30,31]. Therefore, DMC is more probable to inhabit soot formation than other oxygenated fuels. Moreover, the oxygen content in DMC is obviously much larger than other oxygenated fuels $(53.28 \%, 34.73 \%$, $18.15 \%$, and $42.05 \%$ for DMC, ethanol, MTBE, and DMM, respectively), which means small amount of DMC blending with conventional fuels can achieve a higher level of oxygen in the mixture. In addition, the higher boiling point of DMC can help to inhibit the vapor lock at the inlet in evaluation with other oxygenated fuels. In contrast, DMC has a lower boiling point than diesel fuel which is better for the engine performance for cold starting when the ambient temperature is low.

The disadvantages of DMC could be the following. DMC has a low lower-heat value compared to other oxygenated fuels and conventional hydrocarbon fuels $(15.78,26.9,35.2,22.4,42.9$, and $42.5 \mathrm{MJ} / \mathrm{kg}$ for DMC, ethanol, MTBE, DMM, gasoline, and diesel, respectively), which leads to a higher fuel consumption to obtain the same power. That means the load will increase in the oil supply system. Moreover, DMC can absorb much water from the environment, which causes a fuel quality deficiency. In addition, the high latent heat of evaporation and low cetane number for DMC compared to diesel fuel adds some difficulties when using it directly in diesel engines (ignition process) [4].

Based on the issues mentioned above, this paper tries to epitomize the achievements in DMC's production, use in IC engines, and oxidation and combustion kinetics. 
Table 1. The main properties of DMC, other oxygenated, and conventional fuels.

\begin{tabular}{ccccccc}
\hline Properties & DMC [32-34] & Ethanol [35] & MTBE [36] & DMM [36] & Gasoline [35] & Diesel [35] \\
\hline Chemical formula & $\mathrm{C}_{3} \mathrm{H}_{6} \mathrm{O}_{3}$ & $\mathrm{C}_{2} \mathrm{H}_{6} \mathrm{O}$ & $\mathrm{C}_{5} \mathrm{H}_{12} \mathrm{O}$ & $\mathrm{C}_{3} \mathrm{H}_{8} \mathrm{O}_{2}$ & - & - \\
Molar mass $(\mathrm{g} / \mathrm{mol})$ & 90.08 & 46.07 & 88.15 & 76.1 & $100-105$ & $180-200$ \\
Carbon content $(\%)$ & 40 & 52.14 & 68.13 & 47.35 & - & 86 \\
Hydrogen content $(\%)$ & 6.71 & 13.13 & 13.72 & 10.6 & - & 14 \\
Oxygen content $(\%)$ & 53.28 & 34.73 & 18.15 & 42.05 & 0 & 0 \\
Carbon to oxygen ratio $($ by mass) & 0.75 & 1.5 & 3.75 & 1.13 & 0 & 0 \\
Stoichiometric air-fuel ratio & 4.57 & 8.94 & 11.68 & 7.22 & 14.7 & 14.3 \\
Melting point $\left({ }^{\circ} \mathrm{C}\right)$ & 4.6 & -114.14 & -109 & -105 & - & - \\
Flash point $\left({ }^{\circ} \mathrm{C}\right)$ & 21.7 & - & -33 & -18 & -43 & 70 \\
Boiling point $\left({ }^{\circ} \mathrm{C}\right)$ & 90.1 & 78.24 & 55.2 & 42 & $27-225$ & $180-370$ \\
Auto-ignition temperature $\left({ }^{\circ} \mathrm{C}\right)$ & 195 & 434 & 460 & 237 & 420 & 246 \\
Density $\left(\mathrm{kg} / \mathrm{m}^{3}\right.$ at $\left.20^{\circ} \mathrm{C}\right)$ & 1069.4 & 790.9 & 740.4 & 859.3 & 744.6 & 820 \\
Kinematic viscosity $\left(\mathrm{cSt}, 20^{\circ} \mathrm{C}\right)$ & 0.63 & 1.5 & - & - & $0.37-0.44$ & 2.77 \\
Net lower-heat value $(\mathrm{MJ} / \mathrm{kg})$ & 15.78 & 26.9 & 35.2 & 22.4 & 42.9 & 42.5 \\
Latent heat of evaporation $(\mathrm{kJ} / \mathrm{kg})$ & 369 & 919.6 & - & - & 351 & $270-301$ \\
Research octane number $(\mathrm{RON})$ & $101-116$ & 108.7 & 115 & - & $90-100$ & 25 \\
Cetane number & 35 & 8 & - & 30 & $10-15$ & $40-45$ \\
Water solubility $(\mathrm{g} / \mathrm{L})$ & 139 & Miscible & 42 & - & Negligible & - \\
\hline
\end{tabular}

\section{DMC Production Process}

DMC production process can be classified into two main methods: (1) conventional process; and (2) $\mathrm{CO}_{2}$-based process. Conventional methods divide into two methods: phosgene route and non-phosgene route [37]. $\mathrm{CO}_{2}$-based methods include direct synthesis with methanol and integrated processes involving intermediates such as urea, propylene carbonate, and ethylene carbonate.

\subsection{The Conventional Process of DMC Production}

\subsubsection{DMC from Phosgene}

Until the mid-1980s, DMC was produced by the phosgene process [32]. Phosgene $\left(\mathrm{COCl}_{2}\right)$ reacts with methanol $\left(\mathrm{CH}_{3} \mathrm{OH}\right)$ to produce methyl chloroformate $\left(\mathrm{CH}_{3} \mathrm{OCOCl}\right)$, which reacts again with methanol to form $\mathrm{DMC}$ according to the following chemical reaction:

$$
\begin{gathered}
\mathrm{COCl}_{2}+\mathrm{CH}_{3} \mathrm{OH} \rightarrow \mathrm{CH}_{3} \mathrm{OCOCl}+\mathrm{HCl} \\
\mathrm{CH}_{3} \mathrm{OCOCl}+\mathrm{CH}_{3} \mathrm{OH} \rightarrow \mathrm{CH}_{3} \mathrm{OCO}_{2} \mathrm{CH}_{3}+\mathrm{HCl}
\end{gathered}
$$

Overall:

$$
\mathrm{COCl}_{2}+2 \mathrm{ROH} \rightarrow(\mathrm{RO})_{2} \mathrm{CO}+2 \mathrm{HCl}
$$

However, DMC is no longer created by the phosgene process for two reasons: Firstly, phosgene is highly toxic and classified as a class-A poison chemical compound by the United States Department of Transportation (DOT) [38]. Secondly, phosgene and $\mathrm{HCl}$ generated from the above chemical reaction of the process as a second product are corrosive compounds, which affect the equipment [39].

\subsubsection{DMC from Partial Carbonylation (Bayer Process)}

This process employs the non-phosgene method to produce DMC by reacting carbon monoxide, oxygen, and methanol in the liquid or vapor phase [40] as in the reaction below:

$$
\mathrm{CO}+1 / 2 \mathrm{O}_{2}+2 \mathrm{ROH} \rightarrow(\mathrm{RO})_{2} \mathrm{CO}+\mathrm{H}_{2} \mathrm{O}
$$

This method is thermodynamically favorable and operated at moderate conditions [33,40]. The gas-phase oxidative carbonylation of methanol is derived from the liquid-phase method as shown in Equation (4). Chlorine-containing catalysts are the most usually employed in both processes, and playing an important role in the catalytic cycle [41]. The liquid-phase process has a high space-time 
yield (STY) of DMC. However, it suffers from low yield rates, catalyst separation at downstream, equipment corrosion, and rapid deactivation of catalysts by the accumulation of water, and high operating pressure $[40,42]$. To overcome these problems, the gas-phase method was introduced.

\subsubsection{DMC from Methyl Nitrite Process}

As an alternative phosgene-free route, UBE has developed the oxidative reaction which utilizing alkyl nitrites as an oxidant over palladium catalyst (Figure 1) [43]. In this route the chemical reaction can be described as below:

$$
\begin{gathered}
2 \mathrm{ROH}+2 \mathrm{NO}+1 / 2 \mathrm{O}_{2} \rightarrow 2 \mathrm{RONO}+\mathrm{H}_{2} \mathrm{O} \\
2 \mathrm{RONO}+\mathrm{CO} \rightarrow(\mathrm{RO})_{2} \mathrm{CO}+2 \mathrm{NO}
\end{gathered}
$$

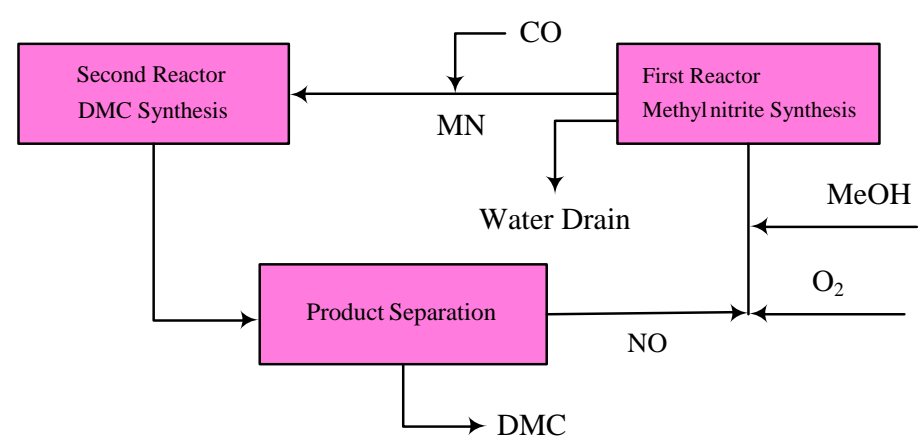

Figure 1. Block diagram of DMC synthesis by UBE process.

In this process, the oxidative agent is alkyl nitrite instead of oxygen for decreasing the risk of explosion. Furthermore, in this route, water does not accumulate, which eliminates adverse effects on catalysts. Therefore, anhydrous condition resulted in high catalytic activity and selectivity for a long reaction time $[38,44]$. However, phosgene-free routes suffer from toxic, corrosive, and explosive chemical compounds.

\subsection{DMC Production from Carbon Dioxide}

In recent years, owing to the increasing emissions of carbon dioxide released from burning fossil fuels, human life and the ecological environment have been affected by global warming and climate changes [45]. The approach of converting waste $\mathrm{CO}_{2}$ into valuable chemical products currently is regarded as a green chemical process [46]. $\mathrm{CO}_{2}$ has been extensively examined by researchers as a raw material to synthesize DMC [47,48]. In general, there are two main synthetic routes of DMC from $\mathrm{CO}_{2}$, i.e., direct reaction of $\mathrm{CO}_{2}$ with methanol, and indirect reaction with intermediate chemical compounds such as urea, propylene carbonate, and ethylene carbonate [34]. Figure 2 illustrates the concept of DMC production via $\mathrm{CO}_{2}$.

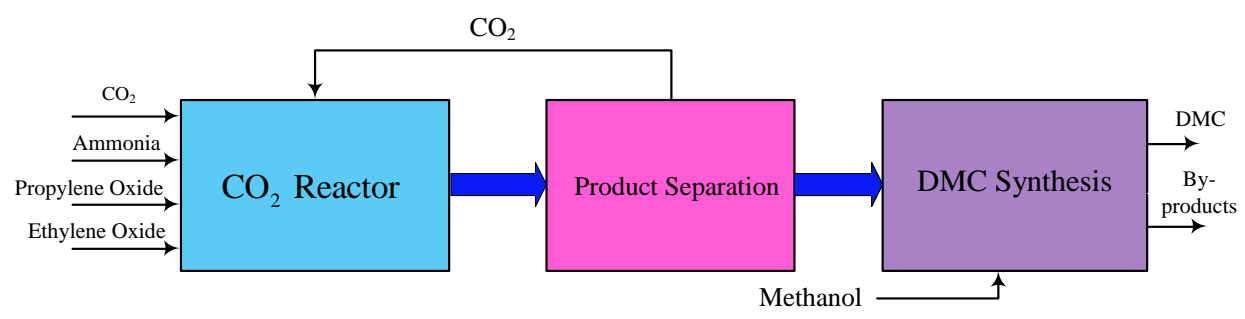

Figure 2. Concept of DMC production from carbon dioxide [49]. 
2.2.1. DMC from Direct Synthesis from $\mathrm{CO}_{2}$ and Alcohol

The direct synthesis of DMC by reaction between $\mathrm{CO}_{2}$ and methanol was first proposed in the 1980s (Equation (7)) [50].

$$
\mathrm{CO}_{2}+2 \mathrm{ROH} \rightarrow(\mathrm{RO})_{2} \mathrm{CO}+\mathrm{H}_{2} \mathrm{O}
$$

This route is considered attractive, sustainable, and challengeable for DMC synthesis based on green chemistry principles. Furthermore, it has many advantages such as safe operation, cheap, simple process, and no intermediate compounds. However, some significant challenges are faced for the high yield of DMC from this route: firstly, activation of $\mathrm{CO}_{2}$ because it lays in a deep potential energy well $-400 \mathrm{~kJ} / \mathrm{mol}$ that demands huge amounts of energy for activation [51,52]; secondly, deactivation of catalyst and hydrolysis of the product [47,53]; and, thirdly, limitation of thermodynamic and reversibility of the reaction [33]. Up to date, this route remains at the laboratory-scale.

2.2.2. DMC Synthesis by Alcoholysis of Urea (Urea-Route)

In this method, ammonia $\mathrm{NH}_{3}$ reacts with $\mathrm{CO}_{2}$ at $165-190{ }^{\circ} \mathrm{C}$ and $135-205$ bar [49] to produce urea $\left(\mathrm{NH}_{2} \mathrm{CONH}_{2}\right)$ which then carries on reacting with methanol to synthesize DMC as shown below,

$$
\begin{gathered}
2 \mathrm{NH}_{3}+\mathrm{CO}_{2} \rightarrow \mathrm{NH}_{2} \mathrm{CONH}_{2}+\mathrm{H}_{2} \mathrm{O} \\
\mathrm{NH}_{2} \mathrm{CONH}_{2}+\mathrm{ROH} \rightarrow \mathrm{ROCONH}_{2}+\mathrm{NH}_{3} \\
\mathrm{ROCONH}_{2}+\mathrm{ROH} \rightarrow(\mathrm{RO})_{2} \mathrm{CO}+\mathrm{NH}_{3}
\end{gathered}
$$

The synthesis of DMC from urea and methanol has numerous advantages such as safe operation, low cost of the raw material, abundant resource, easiness of product separation, and no ternary azeotrope of downstream products [54]. In this route, simple basic catalysts can be used such as $\mathrm{K}_{2} \mathrm{CO}_{3}$, $\mathrm{CH}_{3} \mathrm{ONa}, \mathrm{CaO}$, and $\mathrm{MgO}$ [55]. However, some researchers are introducing activating ionic liquids as catalysts such as $\mathrm{Et}_{3} \mathrm{NHCl}-\mathrm{ZnCl} l_{2}$ or emim $\mathrm{Br}-\mathrm{ZnCl}_{2}$ [56].

\subsubsection{DMC Creation from Propylene Carbonate (PC-Route)}

DMC creation from propylene carbonate and ethylene carbonate is also known as transesterification route. In 1992, this route was applied in industries with high cost and low yield [57]. Transesterification route consists of two steps (Equations (11)-(14)) [58]: the first chemical reaction of $\mathrm{CO}_{2}$ with epoxides produces cyclic carbonates, and, in the second reaction, alcohol reacts with cyclic carbonates by ester exchange to form DMC

$$
\begin{gathered}
\mathrm{C}_{3} \mathrm{H}_{6} \mathrm{O}+\mathrm{CO}_{2} \rightarrow R\left(\mathrm{C}_{2} \mathrm{H}_{3} \mathrm{O}_{2}\right) \mathrm{CO} \\
\left(\mathrm{C}_{2} \mathrm{H}_{3} \mathrm{O}_{2}\right) \mathrm{CO}+2 \mathrm{ROH} \rightarrow(\mathrm{RO})_{2} \mathrm{CO}+\mathrm{C}_{3} \mathrm{H}_{8} \mathrm{O}_{2}
\end{gathered}
$$

Valuable chemical compounds such as propylene glycol $\left(\mathrm{C}_{3} \mathrm{H}_{8} \mathrm{O}_{2}\right)$ and ethylene glycol $\left(\mathrm{C}_{2} \mathrm{H}_{6} \mathrm{O}_{2}\right)$ can be synthesized concomitantly from transesterification route, which enhances the economic efficiency [59]. However, this process faced some problems such as hazardous compounds, the risk of explosion, cost of epoxides, and cost driver in the production of the carbonates [33]. Moreover, the $\mathrm{CO}_{2}$ direct synthesis and propylene carbonate route were less competitive than the other $\mathrm{CO}_{2}$ utilizing routes because of high positive value of Gibbs free energy and low DMC yield [49,60].

\subsubsection{DMC Creation from Ethylene Carbonate (EC-Route)}

DMC creation from ethylene carbonate is one of the most favorable ways to utilize $\mathrm{CO}_{2}$ in DMC production in terms of particle efficiency, energy consumption per one unit of product $(9.13 \mathrm{MJ} / \mathrm{kg})$, and net $\mathrm{CO}_{2}$ emission (11.4\% improvement) [49]. 


$$
\begin{gathered}
\mathrm{C}_{2} \mathrm{H}_{4} \mathrm{O}+\mathrm{CO}_{2} \rightarrow\left(\mathrm{CH}_{2} \mathrm{O}\right)_{2} \mathrm{CO} \\
\left(\mathrm{CH}_{2} \mathrm{O}\right)_{2} \mathrm{CO}+2 \mathrm{ROH} \rightarrow(\mathrm{RO})_{2} \mathrm{CO}+\left(\mathrm{CH}_{2} \mathrm{OH}\right)_{2}
\end{gathered}
$$

\section{The Use of DMC to Fuel IC Engines}

As stated above, DMC has excellent characteristics as a diesel/gasoline additive in IC engines. Typically, DMC was used as an oxygenated additive to enhance combustion and has the potential to reduce emissions from IC engines. In recent years, the use of DMC as pure fuel and oxygenated additive in IC engines has been intensely researched to get high thermal and energy efficiency with low emissions. DMC can mix in any ratio with conventional hydrocarbon fuels without solvents $[7,11]$. Therefore, many researchers have studied the emissions and combustion characteristics of pure DMC, $\mathrm{DMC} /$ diesel and DMC/gasoline in diesel and gasoline engines, respectively.

\subsection{The Use of Pure DMC to Fuel Diesel Engines}

As mentioned in Table 1, DMC has lower-heat value (15.78 MJ $/ \mathrm{kg})$ less than diesel $(42.5 \mathrm{MJ} / \mathrm{kg})$ and higher research octane number (101-116, 25, respectively), which means it can achieve better anti-knock qualities. However, DMC has a low cetane number (35) and high latent heat of vaporization (369 kJ/kg) compared to diesel fuel (40-45, 270-301 kJ/kg). These factors make some difficulties to fuel diesel engines by DMC directly as mentioned in Section 1. Xiaolu et al. [4] proposed a method to combine interior exhaust gas recirculation with a small addition of diesel fuel to burn DMC. The study was conducted on a developed single cylinder, two-stroke engine, with scavenging system. The results showed that DMC had better spray characteristics (size of atomization particles and its distribution) than diesel fuel (base fuel) (Figure 3). In addition, because DMC has low lower-heat value than diesel, $\mathrm{NO}_{x}$ emissions and brake thermal efficiency (2-3\% at moderate and high loads) were enhanced, as shown in Figure 4. However, slight decrease in brake thermal efficiency at low load zone was observed. They explained that with two reasons: hydrocarbon $(H C)$ emissions (refers to incomplete combustion and quality of air-fuel mixture through the combustion process) is higher than base fuel which affects on the heat release from the combustion process, and the in-cylinder temperature is low which reflects on propagation velocity of the flame. Low DMC cetane number and high latent heat of evaporation tend to reduce the $H C$ emissions at moderate and high loads compared to base fuel. Moreover, the study showed that DMC has short combustion duration, nearly constant pressure combustion, and nearly premix combustion an outcome of the low boiling point of evaporation.
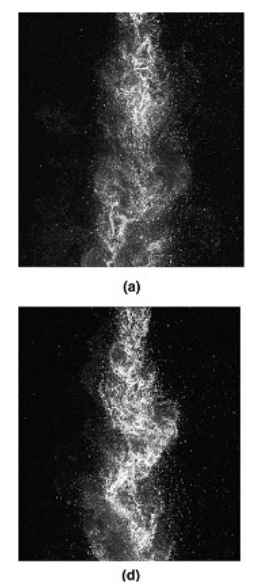

(d)

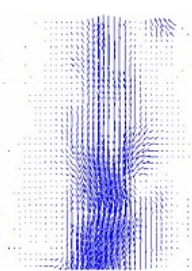

(b)

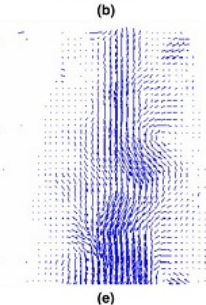

(e)
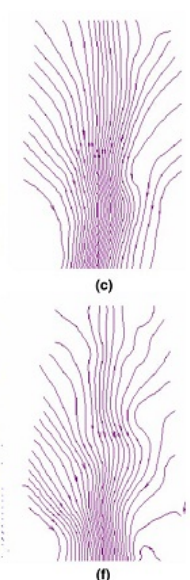

Figure 3. DMC and diesel sprays: (a) DMC spray particle image; (b) DMC spray velocity vector distribution; (c) DMC spray streamline distribution; (d) diesel spray particle image; (e) diesel spray velocity vector distribution; and (f) diesel spray streamline distribution [4]. 

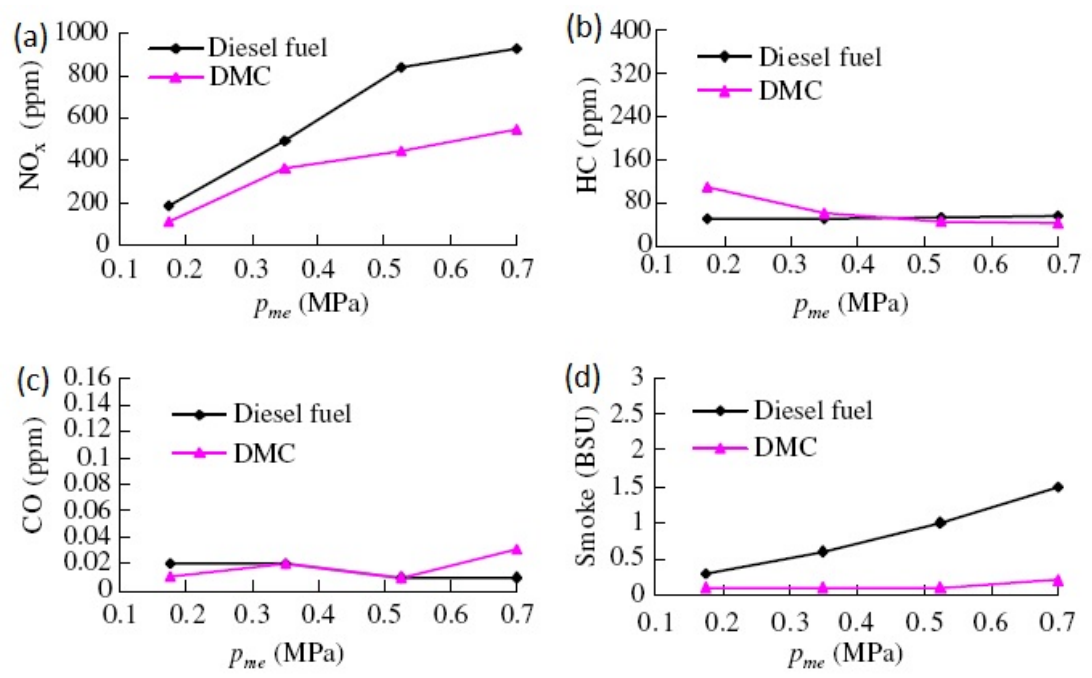

Figure 4. Comparison of the (a) $\mathrm{NO}_{x}$, (b) $\mathrm{HC}$, (c) CO, and (d) smoke emissions at different loads for DMC and base fuel [4].

\subsection{The Use of DMC/Diesel Blends to Fuel Diesel Engines}

Many studies used different fuel supply strategies to investigate the effects of DMC as oxygenated fuel additive, on the emissions and combustion characteristics. The significance of DMC as an additive for diesel fuel comes from its chemical structure. In particular, DMC has no $C-C$ bonds, relatively high $H / C$ ratio, $100 \%$ miscibility in diesel, and contains the highest molecular oxygen content, which leads to smokeless combustion compared to diesel fuel without high-pressure injection and turbocharger. On the other hand, DMC has low cetane number compared to diesel fuel. Huang et al. [5] studied the heat release and combustion characteristics of a direct injection diesel engine fueled by $\mathrm{DMC} /$ diesel blend. The cetane number, maximum gas temperature, and lower-heat value decreased slightly with an increase in DMC addition in blended fuels. However, larger proportion DMC blends such as $20 \mathrm{DMC}(20.3 \% \mathrm{DMC}$ in diesel) were not disperse readily and certainly some agitation was required to achieve a continuous single liquid [6].

Zhang et al. [61] investigated the influences of DMC addition on compression ignition (CI) engine emissions and performances. The experiment was carried out on a water-cooled, four-stroke engine, with fuel delivery advance angles adjusted at 24 and $28^{\circ} \mathrm{CA}$ BTDC (crank angle degrees before top dead center) at $1500 \mathrm{rpm}$. Blended fuel was abbreviated as DMC0, DMC5, DMC10, DMC15, and DMC20. The number following the DMC indicates the volumetric percentage of DMC in the mixture. The study showed that smoke and $\mathrm{NO}_{x}$ emissions were significantly reduced at all ranges of engine loads and both fuel injection timings. These results are due to two reasons: firstly, DMC improves oxygen content in the mixed fuels, decreases $\mathrm{C} / \mathrm{H}$ ratio, and aromatic fraction participates in reducing smoke. Secondly, DMC has high oxygen content which effectively suppresses soot formation in the fuel rich regions. Based on these results, it is found that the thermal efficiency was improved by $1-3 \%$ for DMC15 compared to DMC0. However, delay in combustion ignition of blended fuels was comparable to base fuel because of lower cetane number of mixed fuel while combustion duration is much shorter.

Cheung et al. [62] studied the influence of DMC/diesel $(4.5 \%, 9.1 \%, 13.8 \%$, and $18.6 \%$ by volume) on the gaseous and particulate emissions. The experiment was conducted on a water-cooled, four-cylinder, direct injection engine, operating at five torques: 28, 70,130, 190, and $240 \mathrm{Nm}$. They found that particulate mass concentration and particle number concentration of soot significantly reduced, as shown in Figure 5. This is because of numerous factors such as DMC increased the oxygen content in the mixed fuels, less amount of diesel fuel expended in the diffusion combustion period (which suppressed the creation of a large number of particles), and blended fuel properties changed. 


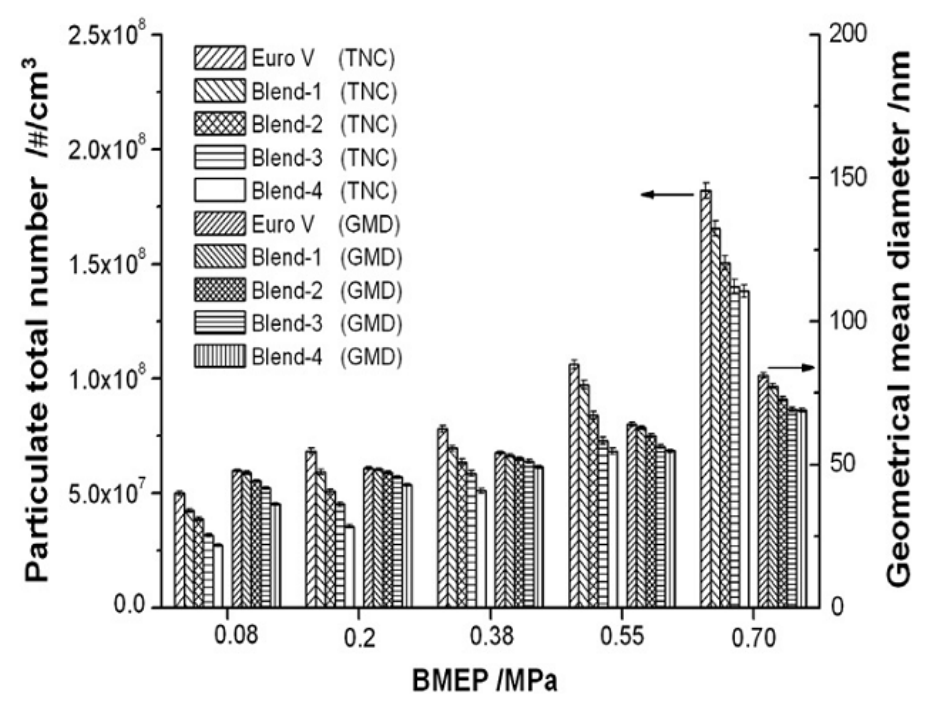

Figure 5. DMC effect on particulate geometric mean diameter (GMD) and total number concentration (TNC) [62].

Mei et al. [13] studied the effect of DMC/diesel blend on combustion process and pollutants of a single cylinder $\mathrm{CI}$ engine. The results showed that volumetric energy density decreased by the addition of DMC to base fuel, while the original power can be achieved by optimizing the injection parameter. $H C, P M$, and $C O$ emissions (formed over unusual carbon dioxide which reduced the availability of oxygen in the combustion process) decreased for a 10\% DMC addition to base fuel due to enhance in oxygen content in the mixed fuel and higher combustion temperature [63], which increased $N O_{x}$ emissions. In addition, the low cetane number of DMC compared to base fuel has no effect on the flammability of the mixed fuel.

Wang et al. [64] investigated the emission characteristics of a diesel engine with oxygenated fuels and exhaust gas recirculation. Fuel consumption increased with the increase of DMC addition percentage in the mixed fuels owing to the low lower-heat value of DMC compared to base fuel. While the brake specific fuel consumption slightly decreased. This result is mainly due to the improvements in combustion process especially diffusion combustion through DMC addition in the blended fuels. In addition, the study established that the effective thermal efficiency enhanced with blended fuels except for 20\% DMC. A small amount of DMC addition enhances combustion process while big amount could reduce the lower-heat value of the mixed fuel. Mehta et al. [63] studied the influence of oxygenated fuel addition on the emissions and performance characteristics of $\mathrm{CI}$ engine. Experiments were performed on a water-cooled, four-stroke, single cylinder engine, with a rated power of $5 \mathrm{hp}$ at $1520 \mathrm{rpm}$. The results showed that soot efficiently was reduced in the case of blended fuels, especially for $5 \%$ DMC. In addition, the research found that brake thermal efficiency increased for 5\% DMC in the fuel while decreased for 10\% DMC and 15\% DMC compared to base fuel.

Rajesh et al. [10] investigated the influence of DMC/diesel mixture (DMC15) on emission and performance characteristics under high torques with charge dilution and combustion phasing controlled by utilizing exhaust gas recirculation $(0-30 \%)$. The study used partially premixed low-temperature combustion (PPLTC) strategy. The results showed that advanced injection timing (21-25 $5^{\circ}$ A BTDC) enhances the engine performance. Mei et al. [65] studied the influences of the center of heat release (COHR) on emissions and combustion in $\mathrm{CI}$ engine fueled by DMC/diesel blend (DMC10). Experiment was conducted on a developed single cylinder engine by using premixed charge compression injection (PCCI) strategy. The results showed that all emissions were reduced for DMC10 compared to base fuel except $N O_{x}$ emissions. $N O_{x}$ emissions and particle matter (PM) could tune 
under various COHR modes. In addition, highest thermal efficiency was obtained for DMC10 at $10^{\circ} \mathrm{CA}$ COHR mode.

\subsection{The Use of DMC/Gasoline Blends to Fuel Gasoline Engines}

As described, DMC has lower $H / C$ ratio (16.78\%) and low lower-heat value (15.78 MJ/kg) than ethanol $(25.18 \%$ and $26.9 \mathrm{MJ} / \mathrm{kg})$, which means it can offer better energy conversion as an additive to gasoline fuel than ethanol [66]. Furthermore, DMC has excellent characteristics as gasoline oxygenated additive such as high octane number, low Reid vapor pressure (RVP), and very high density. Schifter et al. [7] concluded that DMC and ethanol have strongest strain to enhance research octane number in the mixture compared to ethyl-tert-butyl ether (ETBE). Moreover, DMC has the highest oxygen content $(53.28 \mathrm{wt} \%)$ which improves the anti-knock index number $(A K I=(R O N+M O N) / 2)$ in the mixed fuels. DMC/gasoline blend has a better sensitivity (knock characteristics of fuel to engine geometry, $S=R O N-M O N$ ) than ethanol/gasoline.

Wen et al. [8] deeply studied the influence of DMC and methanol addition to unleaded gasoline on exhaust pollution. Blended fuel was abbreviated as E5, E10, E15, D5, D10, and D15. The number following D or E designate the volumetric percentage of DMC and ethanol, respectively. The experiments were carried out on different engine velocities (idle speed, 3500, 5000, 6500, and $8000 \mathrm{rpm}$ ) at a constant load of $3 \mathrm{Nm}$ in a single cylinder, four-stroke, spark-ignition (SI) engine. CO emissions at 3500 and $5000 \mathrm{rpm}$ significantly reduced (at $5000 \mathrm{rpm}$ : 18, 61, 38, 65, 61, 2\% for E5, E10, E15, D5, D10, and D15, respectively, compared to base fuel) while they were less observed at 6500 and $8000 \mathrm{rpm}$. This result is mainly due to two reasons: firstly, oxygen contained in the blended fuel is higher than that in the case of base fuel which enhances the combustion process. Secondly, higher engine speed makes combustion time shorter. Based on aforementioned results, it is found that the $\mathrm{CO}_{2}$ emissions increased at $5000 \mathrm{rpm}$ compared to base fuel $(3 \%, 14.8 \%, 8.5 \%, 18 \%$, and $17 \%$ for E5, E10, E15, D5, and D10, respectively) while unobserved on $\mathrm{CO}_{2}$ emissions change for D15. They attributed the results to two reasons: (1) the combustion was more complete and then the concentration of $\mathrm{CO}_{2}$ emissions got higher; and (2) The consumption of D15 blended fuel's heating value was more than other blended fuels. Moreover, D10 and D15 reduced the $\mathrm{CO}_{2}$ emissions at 6500 and $8000 \mathrm{rpm}$ because, at higher engine speeds, the combustion reaction was incomplete as a result of the low lower-heating value of the blended fuels compared to base fuel. Furthermore, $H C$ emissions showed a significant reduction at $5000 \mathrm{rpm}$ compared to base fuel $(9.7 \%, 24 \%, 12 \%, 35 \%$, $21.6 \%$, and $8.9 \%$ for E5, E10, E15, D5, D10, and D15, respectively). They explained that the oxygenated characteristic of DMC and ethanol are operative in enhancing the oxidation of hydrocarbons in the air. Nevertheless, E15, D10, and D15 increased HC emissions at 6500 and $8000 \mathrm{rpm}$. The higher engine speed reduces combustion time reaction, which leads to incomplete combustion and lower-heating value of mixed fuels. In addition, $N O_{x}$ emissions had highest values in the exhaust gases at idle speed and $6500 \mathrm{rpm}$ due to the equivalence air-fuel ratio was approximately equal to 1 . When the equivalence air-fuel ratio approaches 1 , the flame and exhaust gases temperatures increase during the combustion process. Meanwhile, when equivalence air-fuel ratio was less or more than 1 , insignificant effect on $N O_{x}$ emissions was observed. Moreover, the study explored that the fuel consumption increased for all engine speeds $(24 \%, 31 \%, 46 \%, 22 \%, 42 \%$, and $56 \%$ for E5, E10, E15, D5, D10, and D15, respectively at $5000 \mathrm{rpm}$ ). This result was because that DMC and ethanol have a low lower-heat value. Therefore, the consumption of mixed fuels increased in order to obtain the same power at the same operating conditions. In addition, other factors such as slightly higher viscosity, high density, and low volatility of DMC affect on mixture formation which leads to slow-down the combustion process [67].

Gopinath et al. [67] investigated the influence of DMC addition to gasoline in an SI engine performance. The research was conducted on a four-cylinders, water-cooled, four-stroke engine, with variable engine speeds $(700,1000,1300,1600$, and $1900 \mathrm{rpm})$ at constant load $10 \mathrm{~kg}$. Pure base fuel, D5, D10, D15, and D20 were tested on the engine. The study presented that the brake thermal efficiency was increased compared to base fuel. At $1500 \mathrm{rpm}$, brake thermal efficiency was improved from $0.5 \%$ 
to $2.5 \%$ for D5, D10, D15, and D20, respectively. This result might be due to the increase of octane number in the mixed fuels and perfect combustion process. Gopinath et al. [67] and Wen et al. [8] obtained same results on $\mathrm{HC}, \mathrm{CO}, \mathrm{CO} 2, \mathrm{NO} x$ emissions.

A literature survey noted the influences of DMC on IC engines pollutants and performance (Table 2).

Table 2. Summary of the effect of DMC on IC engines pollutants and performance.

\begin{tabular}{|c|c|c|c|c|}
\hline & & $\begin{array}{l}\text { Pure DMC in } \\
\text { Diesel Engines }\end{array}$ & $\begin{array}{l}\text { DMC/Diesel in } \\
\text { Diesel Engines }\end{array}$ & $\begin{array}{l}\text { DMC/Gasoline in } \\
\text { Gasoline Engines }\end{array}$ \\
\hline \multirow{4}{*}{ Emissions } & $\mathrm{CO}$ & No effect [4] & Improved [13] & Improved [8] \\
\hline & $\mathrm{HC}$ & Negative effect [4] & Improved [13] & Improved [67] \\
\hline & $\mathrm{CO}_{2}$ & $N / A$ & $N / A$ & Negative effect [8] \\
\hline & $N O_{x}$ & Improved [4] & Controversial $[61,63,65]$ & Controversial $[8,66,67]$ \\
\hline \multirow{3}{*}{ Engine performance } & Brake specific fuel consumption & Negative effect [4] & Negative effect [64] & Negative effect [8] \\
\hline & Exhaust gases temperature & Improved [4] & Improved [65] & Negative effect [8] \\
\hline & Brake thermal efficiency & Improved [4] & Improved [61] & Improved [67] \\
\hline
\end{tabular}

\section{The Oxidation and Combustion Kinetics of DMC}

The mechanism of DMC combustion is a significant issue which must be understood. Many studies of the DMC combustion mechanism have been proposed. The main points discussed in this section are laminar burning characteristics, pyrolysis mechanism, and oxidation mechanism of DMC.

\subsection{Laminar Burning Characteristics of DMC}

The laminar burning characteristics (laminar burning velocity, unstretched laminar burning velocity, Markstein length, critical Peclet number, and cellular critical radius) are related to kinetic mechanism, heat release, and diffusivity of the combustible mixture. The laminar burning velocity refers to fuel burning rate (diffusivity, exothermicity and reactivity) on IC engines, therefore the engine emissions and performance [68]. The unstretched laminar burning velocity refers to the spark ignition stability of the flame [69]. The Markstein length refers to the burning velocity, therefore, flame stability. A negative Markstein length means the flame is unstable, and the diffusional thermal effect is considerable on the flame front, whilst a positive Markstein length indicates the flame is stable because of diffusional thermal effect [70]. The critical Peclet number can be described as the critical radius normalized by the laminar flame thickness of the mixture [71]. The cellular critical radius is defined as the radius where the flame velocity increases significantly [72].

Bardin et al. [73] measured the laminar burning velocities of DMC with air, premixed mixtures at different temperatures $(298,313,338$, and $358 \mathrm{~K})$ and constant pressure (atmospheric pressure) using heat flux method. The results of laminar velocities of nonstretched flames are listed in Table 3 . In addition, DMC consumed slower than ethanol and methanol at same initial temperatures. Moreover, numerical simulation results by Glaude mechanism presented remarkable above-predicts laminar burning velocities. It is likely that an update of reaction rate constants for the fundamental reactions governing laminar burning velocities will significantly improve the performance of the model. Sun et al. [74] found quite accurate model results for the laminar burning velocity in the fuel-rich region and slightly over-predicted results in stoichiometric and fuel-lean zones.

$\mathrm{Yu}$ et al. [75] investigated the laminar burning characteristics (unstretched laminar burning velocity, Markstein length, critical Peclet number, and cellular critical radius) of DMC with air, premixed mixtures at different conditions of pressures, temperatures, and equivalence ratios. The experiments were carried out at constant volume combustion with high-speed Schlieren photograph system. They found that increasing the equivalence ratio and initial pressure of mixture led to decrease the Markstein length and cellular critical radius. Furthermore, unstretched laminar burning velocity increased gradually until firstly until 1.1 of equivalence ratio and then decreased. Moreover, the results showed that increase of initial temperature and pressure of mixture led to increase and decrease in 
unstretched laminar burning velocity, respectively. In addition, the numerical simulation by Glaude mechanism and Chemkin program cannot predict the unstretched flame propagation speed accurately. In addition, the critical Peclet number decreases with the increase of equivalence ratio.

Table 3. Laminar burning velocities of DMC with air at $298^{a}, 313,338$, and $358 \mathrm{~K}$ [73].

\begin{tabular}{|c|c|c|c|c|}
\hline Equivalence Ratio & $S_{L}$ at $298 \mathrm{~K}(\mathrm{~cm} / \mathrm{s})$ & $S_{L}$ at $313 \mathrm{~K}(\mathrm{~cm} / \mathrm{s})$ & $S_{L}$ at $338 \mathrm{~K}(\mathrm{~cm} / \mathrm{s})$ & $S_{L}$ at $358 \mathrm{~K}(\mathrm{~cm} / \mathrm{s})$ \\
\hline 0.65 & 13.05 & - & - & - \\
\hline 0.70 & 16.45 & 18 & 20.25 & 23.25 \\
\hline 0.8 & 22.43 & 24.45 & 27.3 & 30.2 \\
\hline 0.9 & 26.34 & 29.14 & 32.15 & 35.76 \\
\hline 1 & 28.96 & 32.15 & 35.13 & 39.01 \\
\hline 1.1 & - & 32.98 & 36.17 & 39.87 \\
\hline 1.2 & - & 31.87 & 35.13 & 38.67 \\
\hline 1.3 & - & 29.19 & 31.95 & 35.64 \\
\hline 1.4 & - & 24.51 & 27.24 & 29.75 \\
\hline 1.5 & - & 19.99 & 21.3 & 24.8 \\
\hline
\end{tabular}

\subsection{DMC Pyrolysis Mechanism}

It is well-known that the combustion of rich fuel at high temperature induces soot, which hinders the combustion efficiency. In the literature, two methods are adopted to analyze the pyrolysis of DMC. The first one is proposed based on software for instants Chemkin. The second is introduced based on detecting the species which are generated by thermal decomposition.

Sun et al. [74] investigated the pyrolysis of DMC in a laminar flow reactor equipped with gas chromatography (GC) at different pressures (40, 200, and 1040 mbar). The results showed that DMC was burned mostly by unimolecular reaction 1 (R1). The main products of DMC pyrolysis were dimethyl ether (DME, $\left.\mathrm{CH}_{3} \mathrm{OCH}_{3}\right), \mathrm{CO}_{2}$, and $\mathrm{CO}$ ) and minor species were methane $\left(\mathrm{CH}_{4}\right), \mathrm{C}_{2} \mathrm{H}_{6}, \mathrm{C}_{2} \mathrm{H}_{4}$, and $\left.\mathrm{C}_{2} \mathrm{H}_{2}\right)$. R2 produces methyl $\left(\mathrm{CH}_{3}\right)$ and $\mathrm{CH}_{3} \mathrm{O}(\mathrm{C}=\mathrm{O}) \mathrm{O}$ and $\mathrm{CH}_{3} \mathrm{O}(\mathrm{C}=\mathrm{O}) \mathrm{O}$ formed hydrogen atom. The $\mathrm{H}$-atom and $\mathrm{CH}_{3}$ attacked DMC molecule through $\mathrm{R} 7$ and R11, respectively, therefore accelerating the DMC consumption. In addition, increasing pressure led to accelerate DMC pyrolysis process via bimolecular reactions (R7 and R11). In contrast, the unimolecular reactions contribution (R1 and R2) were decreased. The most important reactions for initial steps of DMC decomposition were R1, $\mathrm{R} 2, \mathrm{R} 7$, and $\mathrm{R} 11$. DMC and methyl ester formed $\mathrm{CO}_{2}$ before $\mathrm{CO}$ during pyrolysis process, which is different from the other oxygenated fuel for instance ethers and alcohols. $\mathrm{CH}_{3} \mathrm{O}(\mathrm{C}=\mathrm{O}) \mathrm{OCH}_{2}$ produced abundant $\mathrm{CH}_{3} \mathrm{OCO}$ radical through energy-favored $\beta$-scission following $\mathrm{H}$ abstractions (R19) which directly formed $\mathrm{CO}_{2}$ (R21), as in Figure 6. In addition, DMC pyrolysis process is hard to form $\mathrm{C}_{3}$ and large hydrocarbon species due to no $\mathrm{C}-\mathrm{C}$ bonds in its molecular structure.

Viteri et al. [76] studied the formation of the 16 polluting polycyclic aromatic hydrocarbons (PAHs) during the DMC conversion under pyrolytic conditions: naphthalene (NAPH), acenaphthylene $(\mathrm{ACNY})$, acenaphthene (CAN), fluorene (FLUO), phenanthrene (PHEN), anthracene (ANTH), fluoranthene (FANTH), pyrene (PYR), benzo[a]anthracene (B[a]A), chrysene (CHR), benzo[b]fluoranthene $(\mathrm{B}[\mathrm{b}] \mathrm{F})$, benzo[k]fluoranthene $(\mathrm{B}[\mathrm{k}] \mathrm{F})$, benzo[a]pyrene $(\mathrm{B}[\mathrm{a}] \mathrm{P})$, indeno[1,2,3-cd]pyrene $(\mathrm{I}[1,2,3-\mathrm{cd}] \mathrm{P})$, dibenz[a,h]anthracene (DB[ah]A), and benzo[g,h,i]perylene (B[ghi]P). The experiment was conducted on a vertical quartz flow reactor equipped with gas chromatography-mass spectrometry (GC-MS) at different temperatures (1075-1475 K). The results demonstrated that the maximum formation of PAH occurred at $1375 \mathrm{~K}$ (Figure 7). The dominant PAHs are NAPH and ACNY, while PHEN showed slight decrease. 


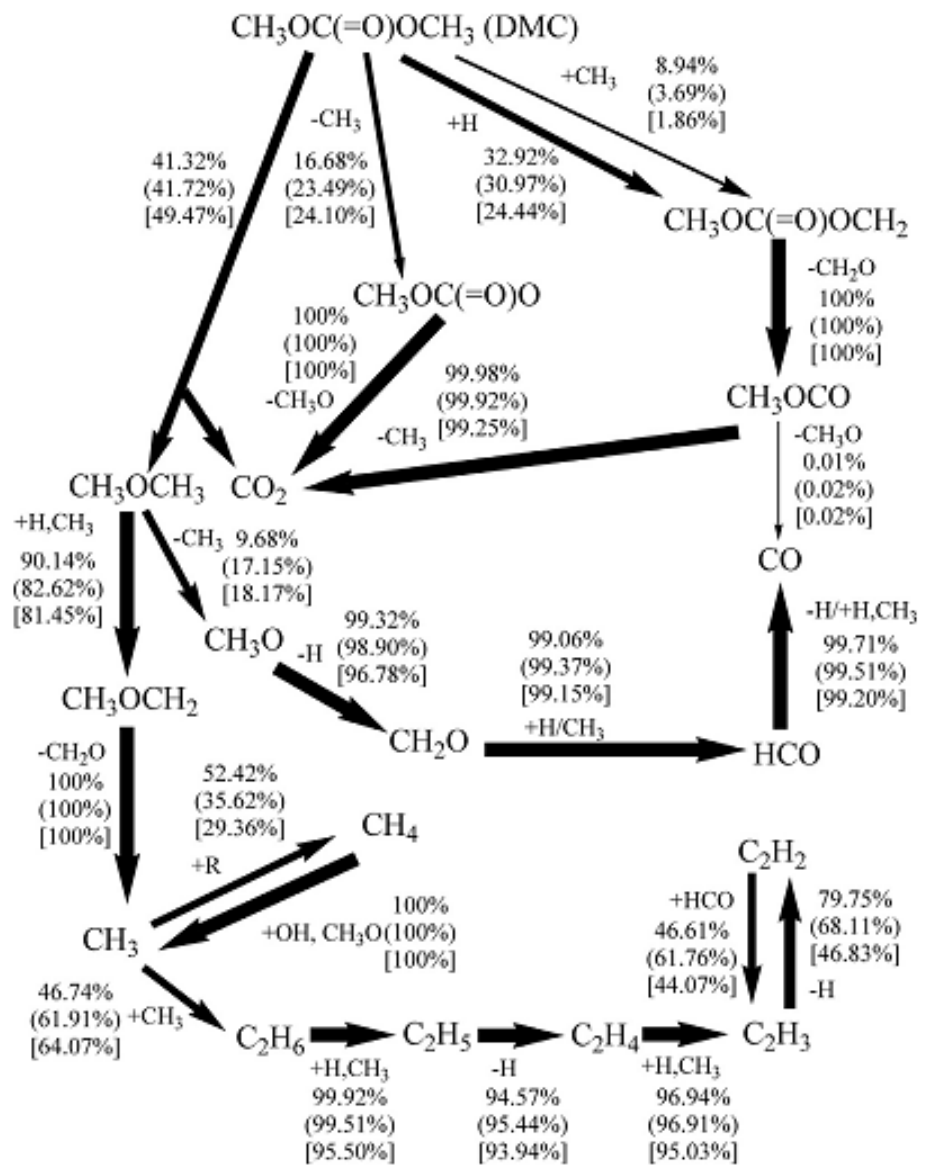

Figure 6. DMC pyrolysis pathway ( $\approx 50 \%$ fuel consumed) in laminar flow reactor at 1040 mbar, 200 mbar (in parentheses) and 40 mbar [in square brackets] [74].

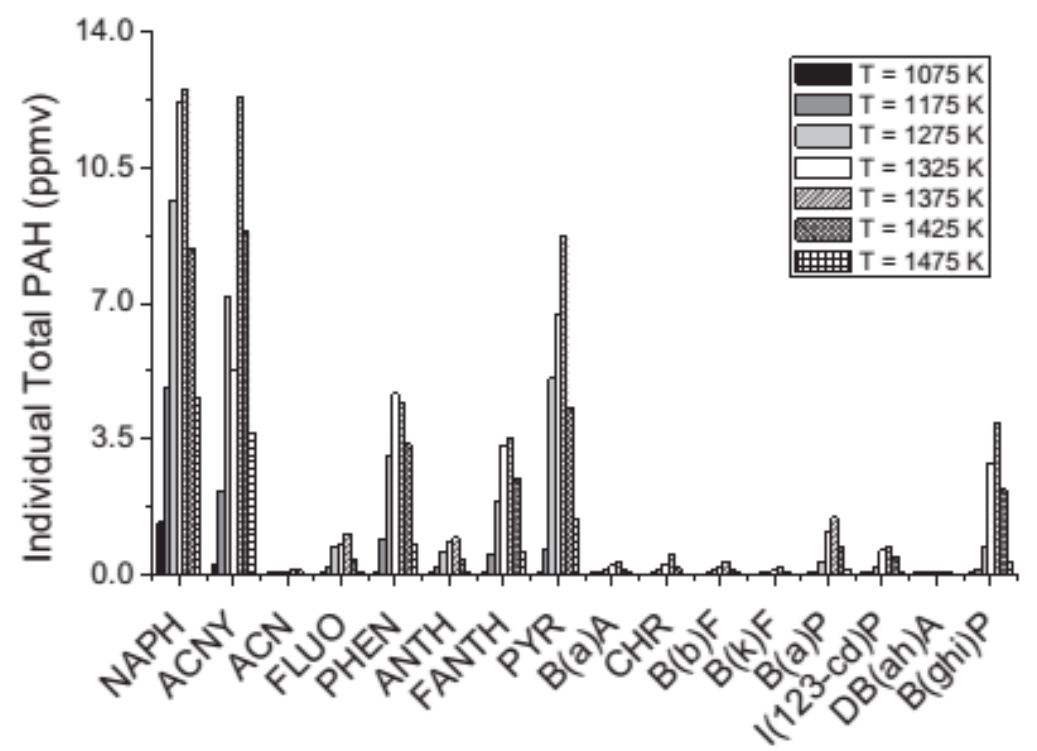

Figure 7. PAH concentrations at different reaction temperatures [76].

Alexandrino et al. [12] studied the sooting tendency of DMC pyrolysis in a flow reactor at different temperatures $(1075,1175,1275,1325,1375,1425$, and $1475 \mathrm{~K})$, DMC concentrations (33,333 
and 50,000 ppm), and constant pressure (atmospheric pressure). The results showed that soot started to form at $1375 \mathrm{~K}$ and hydrogen formation was increased with sharper decrease of $\mathrm{CH}_{4}$ formation. This result is because of methyl radicals $\left(\mathrm{CH}_{3}\right)$ at high temperature contributes to form soot, in contrast at low temperature recycled back to $\mathrm{CH}_{4}$ by $\mathrm{H}_{2}$. DMC pyrolysis produced more $\mathrm{CO} / \mathrm{CO}_{2}$ and limited soot precursors (acetylene and benzene) compared to ethanol, which means less tendency to form soot (Figure 8) [77]. Moreover, DMC concentration slightly increased soot yield and reduced soot reactivity. In addition, higher pyrolysis temperature led to increase the soot yield and reduced soot reactivity.
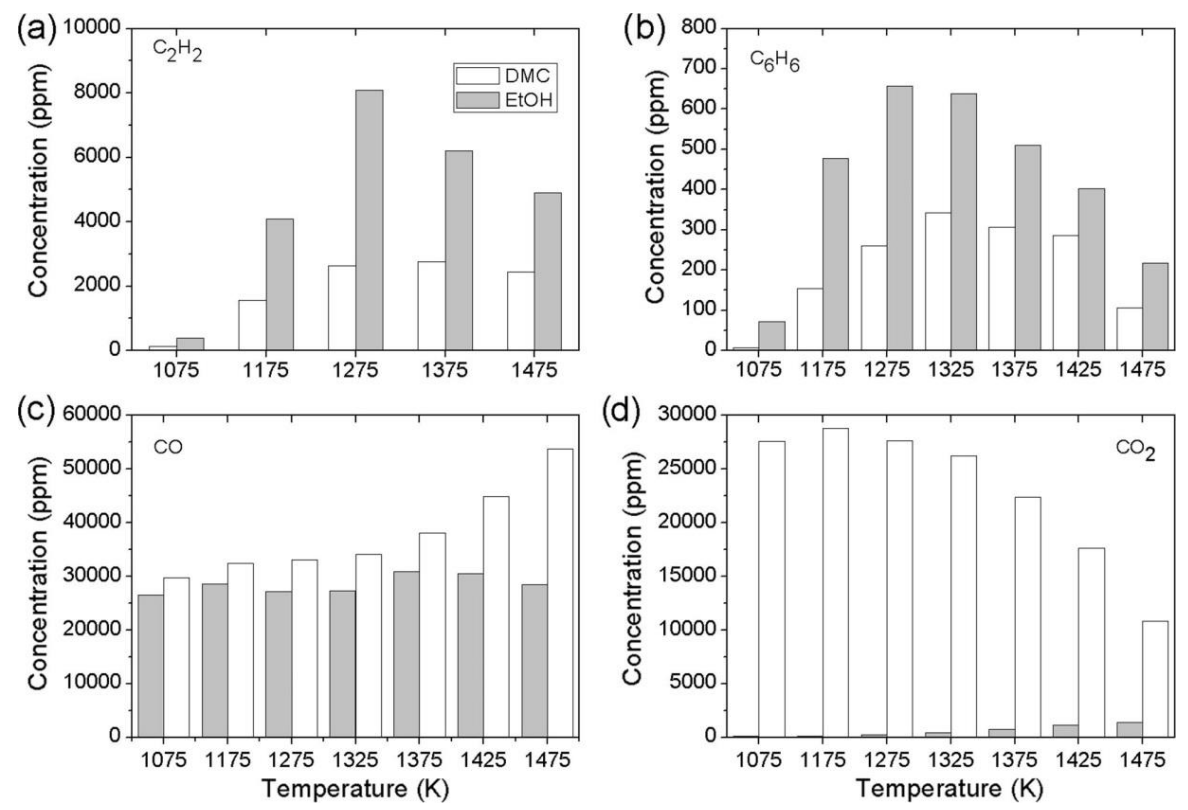

Figure 8. Concentrations of (a) acetylene $\left(\mathrm{C}_{2} \mathrm{H}_{2}\right)$, (b) benzene $\left(\mathrm{C}_{6} \mathrm{H}_{6}\right),(\mathbf{c})$ carbon monoxide $(\mathrm{CO})$, and (d) carbon dioxide $\left(\mathrm{CO}_{2}\right)$ produced by pyrolysis process of DMC and ethanol at different temperatures (1075-1475 K) [12].

\subsection{DMC Oxidation Mechanism}

To investigate the potential of DMC as an alternative fuel for diesel engines or additive for diesel/gasoline fuels, comprehensive details of the kinetic model of the DMC oxidation needed. Therefore, in recent years, the oxidation mechanisms of DMC have been studied by many researchers under different flame conditions, pressures and temperatures.

Sun et al. [74] investigated the low-pressure laminar premixed flames of $\mathrm{DMC} / \mathrm{O}_{2} / \mathrm{Ar}$ at the equivalence ratios of 1 and 1.5 with the vacuum ultraviolet (VUV) ionization in combination with high-resolution mass spectrometry at low pressures (26.66 and $33.33 \mathrm{mbar}$ ). They measured and calculated the rate of production (ROP) and mole fractions of 29 intermediate species, including $\mathrm{CO}_{2}, \mathrm{CO}, \mathrm{Ar}, \mathrm{H}_{2}, \mathrm{H}_{2} \mathrm{O}$, and DMC, $\mathrm{C}_{1}$ species such as $\mathrm{CH}_{3}, \mathrm{CH}_{4}, \mathrm{C}_{2}$ species such as ethane $\left(\mathrm{C}_{2} \mathrm{H}_{6}\right)$, ethylene $\left(\mathrm{C}_{2} \mathrm{H}_{4}\right)$, and $\mathrm{C}_{2} \mathrm{H}_{2}, \mathrm{C}_{3}$ species such as propargyl $\left(\mathrm{C}_{3} \mathrm{H}_{3}\right)$, propyne $\left(\mathrm{C}_{3} \mathrm{H}_{4}-p\right)$, allene $\left(\mathrm{C}_{3} \mathrm{H}_{4}-a\right)$, and propene $\left(\mathrm{C}_{3} \mathrm{H}_{6}\right)$, oxygenated species such as formaldehyde $\left(\mathrm{CH}_{2} \mathrm{O}\right)$, methyl formate $\left(\mathrm{CH}_{3} \mathrm{OCHO}\right)$, acetaldehyde $\left(\mathrm{CH}_{3} \mathrm{CHO}\right)$, and ketene $\left(\mathrm{CH}_{2} \mathrm{CO}\right)$. Isomerization of $\mathrm{CH}_{3} \mathrm{CHO}$ formed ethanol. $\mathrm{CH}_{2} \mathrm{O}$ has the highest concentration in both flames due to decomposition of $\mathrm{CH}_{3} \mathrm{OC}(=\mathrm{O}) \mathrm{OCH}_{2}$ abundant radical through low-energy-barrier $\beta$-scission reaction (R19). In addition, it is found that model showed acceptable agreement with experimental results. DMC flames were produced $\mathrm{CO}_{2}$ and $\mathrm{CO}$ at similar rates in the reaction zone (Figure 9), which is quite different from other hydrocarbon fuels. This result is because of four reasons: (1) DMC direct bond fission produced $\mathrm{CO}_{2}(\mathrm{R} 1)$; (2) the $\mathrm{CH}_{3} \mathrm{OC}(=\mathrm{O}) \mathrm{OCH}_{2}$ formed $\mathrm{CH}_{3} \mathrm{OCO}$ radical, and over $90 \%$ of it breaks down into $\mathrm{CO}_{2}$ and $\mathrm{CH}_{3}$ (R21); (3) direct bond fission of fuel formed $\mathrm{CH}_{3} \mathrm{OC}(=\mathrm{O}) \mathrm{O}$ radicals which completely converted to $\mathrm{CO}_{2}$ and $\mathrm{CH}_{3} \mathrm{O}$ (R20); 
and (4) the reaction $\mathrm{CO}+\mathrm{OH} \rightarrow \mathrm{CO}_{2}+\mathrm{H}$. However, this result may affect the effectiveness of DMC for soot suppression in diesel engines and wasting one oxygen atom to form $\mathrm{CO}_{2}$. Glaude et al. [14] noted that, in the opposed-flow diffusion flame model of DMC, much of oxygen in DMC was formed directly $\mathrm{CO}_{2}$. Each oxygen atom joined to one carbon atom in ideal oxygenated fuel additive, therefore, inhibit the formation of $C-C$ bonds which produces soot.

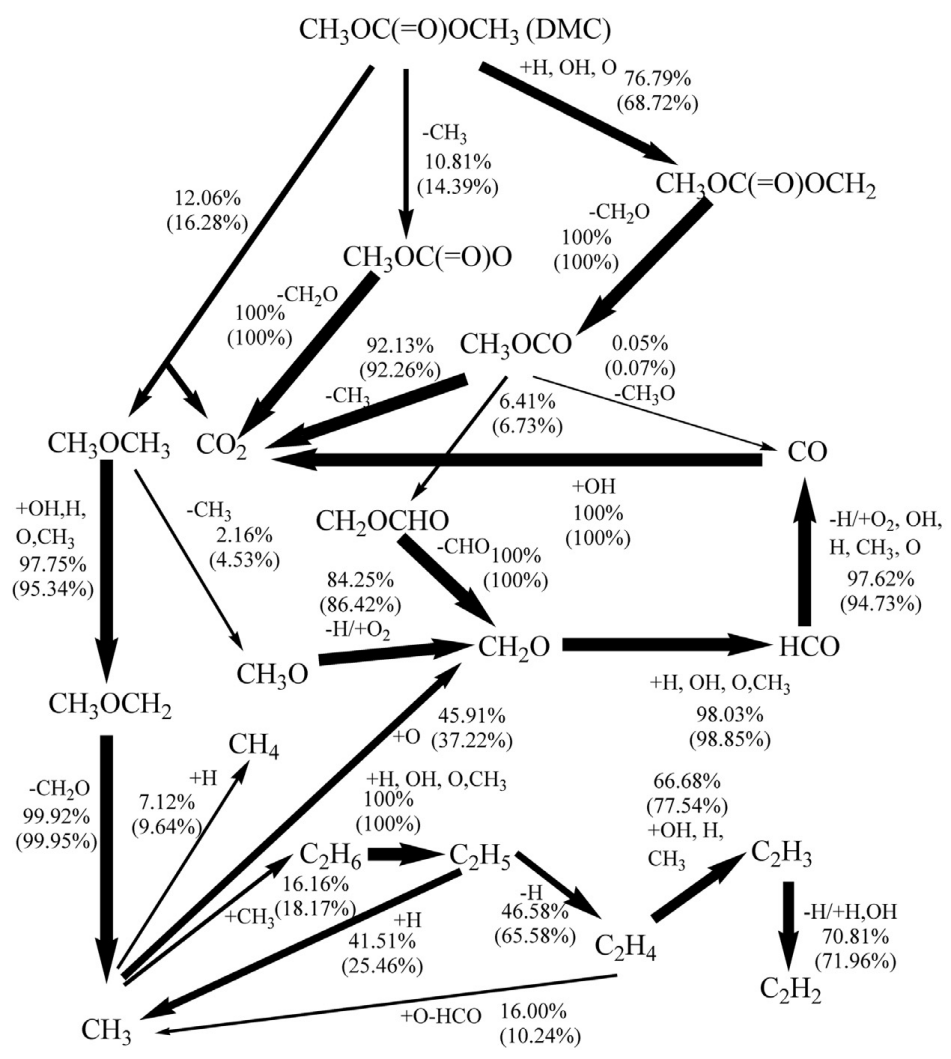

Figure 9. DMC reaction pathways in low-pressure laminar premixed flames for equivalence ratios 1 and 1.5 (in parentheses) [74].

Sinha et al. [78] measured the species concentrations and flame temperatures of pure oxygenated fuel $C_{3}$ (isopropyl alcohol (IPA), DMM, and DMC) and blended with propane $\left(C_{3} H_{8}\right)$ in atmospheric pressure opposed flow diffusion flame coupled with GC. Pure DMC and DMC/propane flames showed a significant reduction in the creation of $\mathrm{CH}_{4}, \mathrm{C}_{2} \mathrm{H}_{2}, \mathrm{C}_{2} \mathrm{H}_{4}$ (93\% reduction compared to propane flame), and $\mathrm{C}_{3} \mathrm{H}_{6}$. These results are due to three reasons: presence of methoxy radical and no $\mathrm{C}-\mathrm{C}$ bonds in DMC. Moreover, DMC has a good effect on the species compared to IPA and DMM (Figure 10). Chen et al. [79] investigated the influence of oxygenated fuels (methanol, DMC, and DMM) blended with n-heptane in laminar premixed flame equipped with synchrotron photoionization and molecular-beam mass spectrometry (PI-MBMS) at 40 mbar. They found that oxygenated fuels additive to n-heptane reduced hydrocarbon species $\left(C_{1}-C_{5}\right)$ by $10-30 \%$ and $C_{6} H_{6}$ was decreased obviously. The model can well predict the concentration of major species in flames. Sun et al. [80] studied the influence of DMC and DMM blended with $\mathrm{C}_{2} \mathrm{H}_{6} / \mathrm{O}_{2} / \mathrm{Ar}$ by $25 \%, 50 \%$, and $75 \%$ mole fraction in premixed laminar flame at $40 \mathrm{mbar}$ and $\mathrm{C} / O$ ratio 0.5 . The model and measured results showed most of the unsaturated hydrocarbons $\left(C_{1}-C_{3}\right)$ were decreased at the levels of DMC and DMM blended fuels due to no $\mathrm{C}-\mathrm{C}$ bonds in their molecular structures. DMM produced more $\mathrm{CH}_{2} \mathrm{O}$ than DMC because of $\mathrm{C}(=\mathrm{O})$ imbedded DMC which cannot contribute to the $\mathrm{CH}_{2} \mathrm{O}$ formation. In addition, although DMM contains two oxygen atoms, DMM showed greater soot/PAH formation separation effect than DMC. 


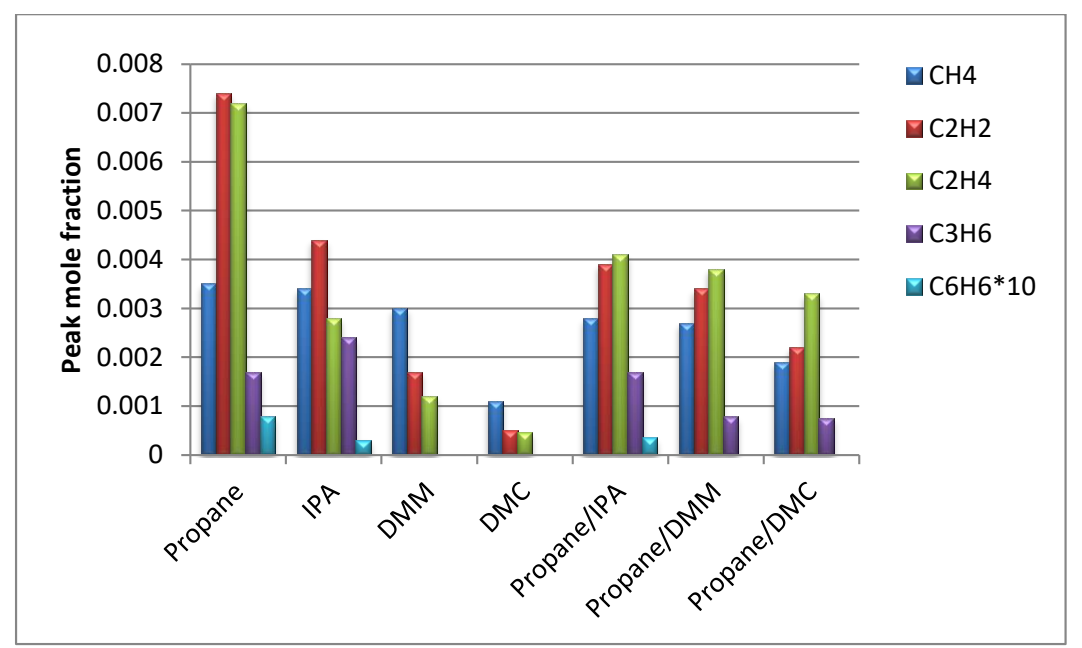

Figure 10. Peak mole fractions of $\mathrm{CH}_{4}, \mathrm{C}_{2} \mathrm{H}_{2}, \mathrm{C}_{2} \mathrm{H}_{4}, \mathrm{C}_{3} \mathrm{H}_{6}$, and $\mathrm{C}_{6} \mathrm{H}_{6}$ for propane, IPA, DMM, DMC, propane/IPA, propane/DMM, and propane/DMC modified from [78].

Alexandrino et al. [11] modeled and measured the DMC ignition delay time in low-pressure (LPST) (DMC/O $/ \mathrm{Ar}$, temperatures range 1220-1585 K, 2 atm.), high-pressure shock tube (HPST) (DMC/air, temperatures range 950-1400 K, 20 and $40 \mathrm{~atm}$.), and rapid compression machine (RCM) (DMC/O $/ \mathrm{O}$, temperatures range 795-975 K, 20 and $40 \mathrm{~atm}$.) at equivalence ratios 0.5, 1, and 2 and DMC concentrations 0.75 and 1.75. There was no flame detected in RCM for fuel-rich mixture at $20 \mathrm{~atm}$. Ignition delay time cannot be measured for stoichiometric and fuel-rich mixtures at $40 \mathrm{~atm}$. in RCM due to the high rate of the heat released during ignition. Moreover, ignition delay time decreased by increasing DMC pressure and concentration for all of the equivalence ratios. This result is due to enhanced reactivity, i.e., reactant concentrations. The effect of equivalence ratios on ignition delay time was found depends on pressure. At lower equivalence ratio $\left(\mathrm{O}_{2}\right.$ increased $)$ with low pressure, reactivity increased by the reaction $\dot{H}+\mathrm{O}_{2} \rightleftharpoons \ddot{O}+\dot{O} H$, which led to decrease the ignition time delay. At high pressure, the reactivity was improved by fuel-specific reactions with increasing equivalence ratio (increasing in DMC concentration). However, high equivalence ratio and pressure at low temperatures significantly reduced the ignition time delay due to many fuel-specific reactions. Hu et al. [81] and Sun et al. [74] obtained the same results for ignition delay time of $\mathrm{DMC} / \mathrm{O}_{2} / \mathrm{Ar}$ in shock tube at temperature range $1100-1600 \mathrm{~K}$; pressures $1.2,5$, and 10 bar; equivalence ratios $0.5,1$, and 2; and DMC concentrations $0.5 \%, 1 \%, 1.5 \%$, and $2 \%$.

Based on the previous studies, one can summarize the DMC oxidation and combustion mechanism as follows:

- $\quad$ DMC was consumed slower than alcohols such as methanol and ethanol.

- Increasing the DMC concentration can only affect slightly the yield of soot without remarkable influence on the gas yield, while the pyrolysis temperature affects soot formation, yields and gas yields.

- Effects of the equivalence ratio on ignition delay time depend on the initial pressure of DMC while increasing in the DMC pressure and concentration decreases the ignition delay time in terms of DMC oxidation and combustion mechanism.

\section{Conclusions and Future Perspectives}

In this review, an overview of DMC synthesis procedures, use of pure DMC and blends with diesel/gasoline fuels in IC engines in terms of pollutants and performance, and oxidation and combustion kinetics is reported. 
Synthesis of DMC based on conventional process (phosgene and non-phosgene routes) suffers from explosions, toxicity, corrosion, low production, catalysts separation, catalysts deactivation, and high operating pressure. Therefore, carbon dioxide routes have been suggested to overcome the drawbacks of the aforementioned problems above. In this way, simple basic catalysts can be used, such as $\mathrm{K}_{2} \mathrm{CO}_{3}, \mathrm{CH}_{3} \mathrm{ONa}, \mathrm{CaO}$, and $\mathrm{MgO}$. Carbon dioxide routes consist of two chemical reaction steps and produce valuable chemical compounds such as propylene glycol and ethylene glycol. Ethylene carbonate route is one of the most promising ways to utilize carbon dioxide and synthesize of DMC in terms of particle efficiency, energy consumption per one unit of product, and net carbon dioxide emission.

In internal combustion engines, pure DMC can directly be used in diesel engines with minor modification. DMC spray demonstrated better characteristics than diesel fuel. Combustion duration becomes shorter because of the low boiling point of DMC. Engine emissions are reduced while carbon monoxide emissions are almost the same. Furthermore, the brake thermal efficiency is increased in moderate and high loads $(2-3 \%)$ while slightly decreases at low loads. In addition, the effects of DMC as an additive to diesel/gasoline fuels are the same as pure DMC effects to some extent. However, $N O_{x}$ emissions is a debatable point.

DMC pyrolysis forms carbon dioxide before carbon monoxide, which is different from other oxygenated fuels, and limited soot precursors are created (acetylene and benzene) compared to ethanol. This is due to $\mathrm{CH}_{3} \mathrm{OC}(=\mathrm{O}) \mathrm{OCH}_{2}$ producing abundant $\mathrm{CH}_{3} \mathrm{OCO}$ radicals, which directly form carbon dioxide. It should be pointed out that DMC prevents large hydrocarbon species from being established. On the other hand, DMC inducesd formaldehyde during oxidation process in high concentration, which is harmful to the environment and human health as well.

To achieve the beneficial use of DMC in the IC engine, two studies are needed: (1) research on DMC/hydrocarbon fuel mixtures for the interaction chemistry; and (2) the present DMC kinetic model needs to update the major reaction constants through recognizing the initial decomposition routes and low-temperature oxidation.

Ultimately, future study should indeed highlight the understanding of the nature of the different catalysts and their integral process to achieve the higher activity, yield, and stability. DMC synthesis yields can be improved if the formed product is removed immediately in the reactor. Currently, researchers are focusing on the yield of products and catalysis. Energy consumption can be reduced by new reactor designs such as multi-function reactor. In addition, the present DMC kinetic model needs to update the major mechanism constants through recognizing the initial decomposition routes and low-temperature oxidation. Moreover, further studies on the DMC/hydrocarbon fuels mixtures for the interaction chemistry are needed.

Author Contributions: A.O.G.A. wrote the paper; and D.L. supervised the work and revised the paper.

Acknowledgments: The authors are thankful for the financial support of the National Natural Science Foundation of China (51576100) and 333 Program of Jiangsu Province (BRA2017428).

Conflicts of Interest: The authors declare no conflict of interest.

\section{References}

1. Fernando, S.; Hall, C.; Jha, S. NOx Reduction from Biodiesel Fuels. Energy Fuels 2006, 20, 376-382. [CrossRef]

2. Beatrice, C.; Di Blasio, G.; Lazzaro, M.; Cannilla, C.; Bonura, G.; Frusteri, F.; Asdrubali, F.; Baldinelli, G.; Presciutti, A.; Fantozzi, F.; et al. Technologies for energetic exploitation of biodiesel chain derived glycerol: Oxy-fuels production by catalytic conversion. Appl. Energy 2013, 102, 63-71. [CrossRef]

3. Fantozzi, F.; Frassoldati, A.; Bartocci, P.; Cinti, G.; Quagliarini, F.; Bidini, G.; Ranzi, E. An experimental and kinetic modeling study of glycerol pyrolysis. Appl. Energy 2016, 184, 68-76. [CrossRef]

4. Xiaolu, L.; Hongyan, C.; Zhiyong, Z.; Zhen, H. Study of combustion and emission characteristics of a diesel engine operated with dimethyl carbonate. Energy Convers. Manag. 2006, 47, 1438-1448. [CrossRef] 
5. Huang, Z.; Jiang, D.; Zeng, K.; Liu, B.; Yang, Z. Combustion characteristics and heat release analysis of a direct injection compression ignition engine fuelled with diesel dimethyl carbonate blends. Proc. Inst. Mech. Eng. Part D J. Automob. Eng. 2003, 217, 595-605. [CrossRef]

6. Rounce, P.; Tsolakis, A.; Leung, P.; York, A. A comparison of diesel and biodiesel emissions using dimethyl carbonate as an oxygenated additive. Energy Fuels 2010, 24, 4812-4819. [CrossRef]

7. Schifter, I.; Gonzlez, U.; Gonzlez-Macas, C. Effects of ethanol, ethyl- tert-butyl ether and dimethyl-carbonate blends with gasoline on SI engine. Fuel 2016, 183, 253-261. [CrossRef]

8. Wen, L.b.; Xin, C.Y.; Yang, S.C. The effect of adding dimethyl carbonate (DMC) and ethanol to unleaded gasoline on exhaust emission. Appl. Energy 2010, 87, 115-121. [CrossRef]

9. Tundo, P.; Selva, M. The chemistry of dimethyl carbonate. Acc. Chem. Res. 2002, 35, 706-716. [CrossRef] [PubMed]

10. Kumar, B.R.; Saravanan, S. Partially premixed low temperature combustion using dimethyl carbonate (DMC) in a DI diesel engine for favorable smoke/NOx emissions. Fuel 2016, 180, 396-406. [CrossRef]

11. Alexandrino, K.; Alzueta, M.U.; Curran, H.J. An experimental and modeling study of the ignition of dimethyl carbonate in shock tubes and rapid compression machine. Combust. Flame 2018, 188, 212-226. [CrossRef]

12. Alexandrino, K.; Salinas, J.; Millera, Á.; Bilbao, R.; Alzueta, M.U. Sooting propensity of dimethyl carbonate, soot reactivity and characterization. Fuel 2016, 183, 64-72. [CrossRef]

13. Mei, D.; Hielscher, K.; Baar, R. Study on Combustion Process and Emissions of a Single Cylinder Diesel Engine Fueled with DMC / Diesel Blend. J. Energy Eng. 2014, 140, 04013004. [CrossRef]

14. Glaude, P.A.; Pitz, W.J.; Thomson, M.J. Chemical kinetic modeling of dimethyl carbonate in an opposed flow diffusion flame. Proc. Combust. Inst. 2005, 30, 1111-1118. [CrossRef]

15. Dias, V.; Vandooren, J. Experimental and modeling studies of $\mathrm{C}_{2} \mathrm{H}_{4} / \mathrm{O}_{2} / \mathrm{Ar}, \mathrm{C}_{2} \mathrm{H}_{4} /$ methylal $/ \mathrm{O}_{2} / \mathrm{Ar}$ and $\mathrm{C}_{2} \mathrm{H}_{4}$ / ethylal $/ \mathrm{O}_{2} / \mathrm{Ar}$ rich flames and the effect of oxygenated additives. Combust. Flame 2011, 158, 848-859. [CrossRef]

16. Noorman, M.T. The Effect of MTBE, DIPE and TAME on Vehicle Emissions. Exhaust Emiss. 1993. [CrossRef]

17. Kivi, J.; Niemi, A.; Nylund, N.O.; Kyt, M.; Orre, K. Use of MTBE and ETBE as Gasoline Reformulation Components. SAE Tech. Pap. 1992, 22, 209-226.

18. Mennear, J.H. Carcinogenicity Studies on MTBE: Critical Review and Interpretation. Risk Anal. 1997, 17, 673. [CrossRef] [PubMed]

19. Keller, A.A.; Sandall, O.C.; Rinker, R.G.; Mitani, M.M.; Bierwagen, B.; Snodgrass, M.J. Cost and Performance Evaluation of Treatment Technologies for MTBE-Contaminated Water. UC TSR\&TP Report to the Governor of California, 1998. Available online: https://www.researchgate.net/publication/243778975_ Cost_and_Performance_Evaluation_of_Treatment_Technologies_for_MTBE-Contaminated_Water (accessed on 5 June 2018).

20. Keller, A.A.; Bierwagen, B.; Sirivithayapakorn, S.; Kram, M. Advances In Groundwater Treatment To Remove Mtbe. In Hazardous and Industrial Waste Proceedings, 31st Mid-Atlantic Conference; CRC Press: Boca Raton, FL, USA, 2007.

21. Kampbell, D.H.; An, Y.J.; Williams, V.R. Influence of Methyl tert -Butyl Ether on Lake Water Algae. Bull. Environ. Contam. Toxicol. 2001, 67, 574-579. [CrossRef] [PubMed]

22. Bretherick, L. Gasoline Motor Fuels Containing Dialkyl Carbonate-As Octane Improver. EP Patent 82688, 29 June 1983.

23. Short, G.D.; Spencer, M.S. Gasoline Compositions Foric Engine-Comprises Gasoline Hydrocarbon and Dimethyl Carbonate. EP Patent 98691, 18 April 1984.

24. Jessup, P.J.; Brass, S.G.; Croudace, M.C. Gasoline Compositions Containing Carbonates. U.S. Patent 06728244, 29 April 1986.

25. Smith, H.A. Dialkyl Carbonates as Phase Separation Inhibitors in Liquid Hydrocarbon Fuel and Ethanol Mixtures. U.S. Patent 06353691, 1 March 1983.

26. Jiang, C.; Guo, Y.; Wang, C.; Hu, C.; Wu, Y.; Wang, E. Synthesis of dimethyl carbonate from methanol and carbon dioxide in the presence of polyoxometalates under mild conditions. Appl. Catal. A Gen. 2003, 256, 203-212. [CrossRef]

27. Liotta, F.J.; Montalvo, D.M. The effect of oxygenated fuels on emissions from a modern heavy duty diesel engine. SAE Tech. Pap. 1993. [CrossRef] 
28. Westbrook, C.K.; Pitz, W.J.; Curran, H.J. Chemical Kinetic Modeling Study of the Effects of Oxygenated Hydrocarbons on Soot Emissions from Diesel Engines. J. Phys. Chem. A 2006, 110, 6912-6922. [CrossRef] [PubMed]

29. Miyamoto, N.; Ogawa, H.; Arima, T.; Miyakawa, K. Improvement of Diesel Combustion and Emissions with Addition of Various Oxygenated Agents to Diesel Fuels. SAE Tech. Pap. 1996, 11-26. [CrossRef]

30. Renard, C.; Tiggelen, P.J.V.; Vandooren, J. Effect of dimethoxymethane addition on the experimental structure of a rich ethylene/oxygen/argon flame. Proc. Combust. Inst. 2002, 29, 1277-1284. [CrossRef]

31. Dias, V.; Katshiatshia, H.M.; Jeanmart, H. The influence of ethanol addition on a rich premixed benzene flame at low pressure. Combust. Flame 2014, 161, 2297-2304. [CrossRef]

32. Pacheco, M.A.; Marshall, C.L. Review of Dimethyl Carbonate (DMC) Manufacture and Its Characteristics as a Fuel Additive. Energy Fuels 1997, 11, 2-29. [CrossRef]

33. Huang, S.; Yan, B.; Wang, S.; Ma, X. ChemInform Abstract: Recent Advances in Dialkyl Carbonates Synthesis and Applications. Chem. Soc. Rev. 2015, 44, 3079. [CrossRef] [PubMed]

34. Pyo, S.H.; Ji, H.P.; Chang, T.S.; Hatti-Kaul, R. Dimethyl carbonate as a green chemical. Curr. Opin. Green Sustain. Chem. 2017, 5, 61-66. [CrossRef]

35. Qian, Y.; Zhu, L.; Wang, Y.; Lu, X. Recent progress in the development of biofuel 2,5-dimethylfuran. Renew. Sustain. Energy Rev. 2015, 41, 633-646. [CrossRef]

36. Arteconi, A.; Mazzarini, A.; Di Nicola, G. Emissions from ethers and organic carbonate fuel additives: A review. Water Air Soil Pollut. 2011, 221, 405. [CrossRef]

37. Bhanage, B.M.; Fujita, S.I.; Ikushima, Y.; Arai, M. Synthesis of dimethyl carbonate and glycols from carbon dioxide, epoxides, and methanol using heterogeneous basic metal oxide catalysts with high activity and selectivity. Appl. Catal. A Gen. 2001, 219, 259-266. [CrossRef]

38. Matsuzaki, T.; Nakamura, A. Dimethyl carbonate synthesis and other oxidative reactions using alkyl nitrites. Catal. Surv. Asia 1997, 1,77-88. [CrossRef]

39. Aricò, F.; Tundo, P. Dimethyl carbonate: A modern green reagent and solvent. Russ. Chem. Rev. 2010, 79, 479-489. [CrossRef]

40. Han, M.S.; Lee, B.G.; Suh, I.; Kim, H.S.; Ahn, B.S.; Hong, S.I. Synthesis of dimethyl carbonate by vapor phase oxidative carbonylation of methanol over Cu based catalysts. J. Mol. Catal. A Chem. 2001, 170, 225-234. [CrossRef]

41. Sato, Y.; Kagotani, M.; Souma, Y. A new type of support 'bipyridine containing aromatic polyamide' to $\mathrm{CuCl}_{2}$ for synthesis of dimethyl carbonate (DMC) by oxidative carbonylation of methanol. J. Mol. Catal. A Chem. 2000, 1-2, 79-85. [CrossRef]

42. Itoh, H.; Watanabe, Y.; Mori, K.; Umino, H. Synthesis of dimethyl carbonate by vapor phase oxidative carbonylation of methanol. Green Chem. 2003, 5, 558-562. [CrossRef]

43. Yamamoto, Y. Vapor Phase Carbonylation Reactions Using Methyl Nitrite Over Pd Catalysts. Catal. Surv. Asia 2010, 14, 103-110. [CrossRef]

44. Delledonne, D.; Rivetti, F.; Romano, U. Developments in the production and application of dimethylcarbonate. Appl. Catal. A Gen. 2001, 221, 241-251. [CrossRef]

45. Wang, W.; Wang, S.; Ma, X.; Gong, J. Recent advances in catalytic hydrogenation of carbon dioxide. Chem. Soc. Rev. 2011, 40, 3703-3727. [CrossRef] [PubMed]

46. Choi, J.C.; Sakakura, T.; Sako, T. Reaction of Dialkyltin Methoxide with Carbon Dioxide Relevant to the Mechanism of Catalytic Carbonate Synthesis. J. Am. Chem. Soc. 1999, 121, 3793-3794. [CrossRef]

47. Zhao, T.; Han, Y.; Sun, Y. Novel reaction route for dimethyl carbonate synthesis from $\mathrm{CO}_{2}$ and methanol. Fuel Proc. Technol. 2000, 62, 187-194. [CrossRef]

48. Yu, K.M.; Curcic, I.; Gabriel, J.; Tsang, S.C. Recent advances in $\mathrm{CO}_{2}$ capture and utilization. Chemsuschem 2008, 1, 893-899. [CrossRef] [PubMed]

49. Kongpanna, P.; Pavarajarn, V.; Gani, R.; Assabumrungrat, S. Techno-economic evaluation of different $\mathrm{CO}_{2}$ based processes for dimethyl carbonate production. Chem. Eng. Res. Des. 2015, 93, 496-510. [CrossRef]

50. Hoffman, W.A., III. A convenient preparation of carbonates from alcohols and carbon dioxide. J. Org. Chem. 1982, 47, 5209-5210. [CrossRef]

51. Eta, V.; Mäki-Arvela, P.; Wärnå, J.; Salmi, T.; Mikkola, J.P.; Murzin, D.Y. Kinetics of dimethyl carbonate synthesis from methanol and carbon dioxide over $\mathrm{ZrO}_{2} \mathrm{MgO}$ catalyst in the presence of butylene oxide as additive. Appl. Catal. A Gen. 2011, 404, 39-46. [CrossRef] 
52. Aresta, M. Perspectives in the use of carbon dioxide. Química Nova 1999, 22, 269-272. [CrossRef]

53. Guo, X.C.; Qin, Z.F.; Wang, G.F.; Wang, J.G. Critical temperatures and pressures of reacting mixture in synthesis of dimethyl carbonate with methanol and carbon dioxide. Chin. Chem. Lett. 2008, 19, $249-252$. [CrossRef]

54. Shukla, K.; Srivastava, V.C. Synthesis of organic carbonates from alcoholysis of urea: A review. Catal. Rev. 2017, 59, 1-43. [CrossRef]

55. Wang, M.; Wang, H.; Zhao, N.; Wei, W.; Sun, Y. Synthesis of dimethyl carbonate from urea and methanol over solid base catalysts. Catal. Commun. 2006, 7, 6-10. [CrossRef]

56. Wang, H.; Lu, B.; Wang, X.; Zhang, J.; Cai, Q. Highly selective synthesis of dimethyl carbonate from urea and methanol catalyzed by ionic liquids. Fuel Proc. Technol. 2009, 90, 1198-1201. [CrossRef]

57. Haggin, J. Catalytic cosynthesis method developed. Chem. Eng. News 1992, 70, 25-26. [CrossRef]

58. Knifton, J.F.; Duranleau, R.G. Ethylene glycol dimethyl carbonate cogeneration. J. Mol. Catal. 1991, 67, 389-399. [CrossRef]

59. Santos, B.A.; Silva, V.M.; Loureiro, J.M.; Rodrigues, A.E. Review for the direct synthesis of dimethyl carbonate. ChemBioEng Rev. 2014, 1, 214-229. [CrossRef]

60. Murugan, C.; Bajaj, H. Transesterification of Propylene Carbonate With Methanol Using $\mathrm{Mg}-\mathrm{Al}-\mathrm{CO}_{3}$ Hydrotalcite as Solid Base Catalyst. Catal. Lett. 2010, 137, 224-231. [CrossRef]

61. Zhang, G.; Liu, H.; Xia, X.; Zhang, W.; Fang, J. Effects of dimethyl carbonate fuel additive on diesel engine performances. Proc. Inst. Mech. Eng. Part D J. Automob. Eng. 2005, 219, 897-903. [CrossRef]

62. Cheung, C.; Zhu, R.; Huang, Z. Investigation on the gaseous and particulate emissions of a compression ignition engine fueled with diesel dimethyl carbonate blends. Sci. Total Environ. 2011, 409, 523-529. [CrossRef] [PubMed]

63. Mehta, B.H.; Mandalia, H.V.; Mistry, A.B. A review on effect of oxygenated fuel additive on the performance and emission characteristics of diesel engine. In Proceedings of the National Conference on Recent Trends in Engineering \& Technology, Anand, India, 13-14 May 2011; pp. 13-14.

64. Wang, H.; Huang, Z.; Zhou, L.; Jiang, D.; Yang, Z. Investigation on emission characteristics of a compression ignition engine with oxygenated fuels and exhaust gas recirculation. Proc. Inst. Mech. Eng. Part D J. Automob. Eng. 2000, 214, 503-508. [CrossRef]

65. Mei, D.; Yue, S.; Zhao, X.; Hielscher, K.; Baar, R. Effects of center of heat release on combustion and emissions in a PCCI diesel engine fuelled by DMC diesel blend. Appl. Therm. Eng. 2017, 114, 969-976. [CrossRef]

66. Schifter, I.; Gonzalez, U.; Diaz, L.; Sanchez Reyna, G.; Mejia Centeno, I.; Gonzalez Macias, C. Comparison of performance and emissions for gasoline oxygenated blends up to 20 percent oxygen and implications for combustion on a spark ignited engine. Fuel 2017, 208, 673-681. [CrossRef]

67. Gopinath, D.; Sundaram, E.G. Experimental Investigation on the Effect of Adding Di Methyl Carbonate to Gasoline in a SI Engine Performance. Int. J. Sci. Eng. Res. 2012, 3, 1-5.

68. Xu, C.; Zhong, A.; Li, X.; Wang, C.; Sahu, A.; Xu, H.; Lattimore, T.; Zhou, K.; Huang, Y. Laminar burning characteristics of upgraded biomass pyrolysis fuel derived from rice husk at elevated pressures and temperatures. Fuel 2017, 210, 249-261. [CrossRef]

69. Wu, X.; Huang, Z.; Jin, C.; Wang, X.; Wei, L. Laminar burning velocities and Markstein lengths of 2, 5 dimethylfuran-air premixed flames at elevated temperatures. Combust. Sci. Technol. 2010, 183, 220-237. [CrossRef]

70. Kitagawa, T. Effects of pressure on burning velocity and instabilities of propane air premixed flames. JSME Int. J. Ser. B Fluids Therm. Eng. 2005, 48, 2-8. [CrossRef]

71. Gu, X.J.; Haq, M.Z.; Lawes, M.; Woolley, R. Laminar burning velocity and Markstein lengths of methane air mixtures. Combust. Flame 2000, 121, 41-58. [CrossRef]

72. Xie, Y.; Wang, J.; Cai, X.; Huang, Z. Self-acceleration of cellular flames and laminar flame speed of syngas/air mixtures at elevated pressures. Int. J. Hydrogen Energy 2016, 41, 18250-18258. [CrossRef]

73. Bardin, M.E.; Ivanov, E.V.; Nilsson, E.J.; Vinokurov, V.A.; Konnov, A.A. Laminar burning velocities of dimethyl carbonate with air. Energy Fuels 2013, 27, 5513-5517. [CrossRef]

74. Sun, W.; Yang, B.; Hansen, N.; Westbrook, C.K.; Zhang, F.; Wang, G.; Moshammer, K.; Law, C.K. An experimental and kinetic modeling study on dimethyl carbonate (DMC) pyrolysis and combustion. Combust. Flame 2016, 164, 224-238. [CrossRef] 
75. Yu, H.; Hu, E.; Yang, K.; Huang, Z. Experimental and Numerical Research on Laminar Burning Characteristics of Premixed Dimethyl Carbonate/Air Flames. J. Xi'an Jiaotong Univ. 2014, 48, $25-31$.

76. Viteri, F.; Salinas, J.; Millera, Á.; Bilbao, R.; Alzueta, M. Pyrolysis of dimethyl carbonate: PAH formation. J. Anal. Appl. Pyrolysis 2016, 122, 524-530. [CrossRef]

77. Alzueta, M.U.; Salinas, P.; Millera, Á.; Bilbao, R.; Abián, M. A study of dimethyl carbonate conversion and its impact to minimize soot and NO emissions. Proc. Combust. Inst. 2017, 36, 3985-3993. [CrossRef]

78. Sinha, A.; Thomson, M. The chemical structures of opposed flow diffusion flames of $\mathrm{C}_{3}$ oxygenated hydrocarbons (isopropanol, dimethoxy methane, and dimethyl carbonate) and their mixtures. Combust. Flame 2004, 136, 548-556. [CrossRef]

79. Chen, G.; Yu, W.; Fu, J.; Mo, J.; Huang, Z.; Yang, J.; Wang, Z.; Jin, H.; Qi, F. Experimental and modeling study of the effects of adding oxygenated fuels to premixed n-heptane flames. Combust. Flame 2012, 159, 2324-2335. [CrossRef]

80. Sun, W.; Yang, B.; Hansen, N.; Moshammer, K. The influence of dimethoxy methane (DMM)/dimethyl carbonate (DMC) addition on a premixed ethane/oxygen/argon flame. Proc. Combust. Inst. 2017, 36, 449-457. [CrossRef]

81. Hu, E.; Chen, Y.; Zhang, Z.; Pan, L.; Li, Q.; Cheng, Y.; Huang, Z. Experimental and kinetic study on ignition delay times of dimethyl carbonate at high temperature. Fuel 2015, 140, 626-632. [CrossRef]

(C) 2018 by the authors. Licensee MDPI, Basel, Switzerland. This article is an open access article distributed under the terms and conditions of the Creative Commons Attribution (CC BY) license (http://creativecommons.org/licenses/by/4.0/). 